\title{
“Isto não é um filme” de Jafar Panahi: a denúncia contra censura pela metanarrativa
}

"This is not a film" by Jafar Panahi: denunciation against censorship by metanarrative language

“Esto no es una pelicula” de Jafar Panahi: la denuncia contra censura por la metanarrativa

DOI: https://doi.org/10.1590/1809-5844202118

\section{Pedro Piccoli Garcia ${ }^{1}$}

http://orcid.org/0000-0001-6379-9305

\section{Fabiana Quatrin Piccinin ${ }^{1}$}

http://orcid.org/0000-0003-4792-5716

${ }_{1}^{1}$ (Universidade de Santa Cruz do Sul, Departamento de Comunicação Social, Programa de Pós-Graduação em Letras. Santa Cruz do Sul - RS, Brasil).

\section{Resumo}

O artigo discute a estética do cinema de Jafar Panahi que, proibido de fazer filmes, adota a metanarrativa como estratégia de linguagem e de denúncia do sistema político. Objetiva-se, assim, refletir sobre o cinema que radicaliza o tensionamento das fronteiras entre ficção e não ficção, tanto como forma de denunciar a injustiça da qual o autor é vítima, quanto para problematizar os limites da narrativa cinematográfica. Toma-se, para tanto, o filme "Isto Não É Um Filme” (2010), entendendo como uma produção característica das narrativas pós-modernas, marcada pela oferta de sentidos que promete o acesso ao real tanto quanto possível, buscando romper com o tradicional escamoteamento das marcas de enunciação do cinema, ao voltar-se a si mesmo, incorporando os bastidores à trama principal. São analisadas sequências do filme a partir de categorias resultantes de padrões repetição: a) a câmera como elemento intradigético e metanarrativo; b) o mise en abyme, c) $\mathrm{O}$ realizador como personagem. Palavras-chave: Metanarrativa. Pós-modernidade. Censura. Cinema iraniano. Jafar Panahi.

\begin{abstract}
This article discusses metanarrative as Jafar Panahi's strategy of narrative articulation and denunciation, who was banned by the Iranian government from making films. It aims to reflect on how the production "This Is Not a Film" radicalizes the tension the boundaries between fiction and non-fiction, denouncing the injustice in which the director is a victim of. The analysis comes from three categories: a) the camera as an intradiegetic and metanarrative element; b) the mise en abyme, and c) the director as a character. It is concluded that the film is a production of contemporary aesthetics, stamped by narratives where meaning proposes problematic access to the real, in the
\end{abstract}


supposed rupture with canonical rules of cinema when breaking the fourth wall, making the alleged concealment of the marks of enunciation an important narrative articulation, in order to transgress and also make it visible to the censorship imposed in the country, by incorporating the backstage to the main plot, in a movement of the film to turn back to itself.

Keywords: Metanarrative language. Postmodernity. Censorship. Iranian movies. Jafar Panahi.

\section{Resumen}

El artículo discute la metanarrativa como estrategia de articulación narrativa y de denuncia en el cine de Jafar Panahi, prohibido por el gobierno iraní de hacer películas. Se pretende reflejar cómo la obra "Esto no es una película" radicaliza la tensión de las fronteras entre ficción y no ficción, denunciando la injusticia de la que el director es víctima. El análisis se da a partir de tres categorías: (a) la cámara como elemento intradiegético y metanarrativo; (b) el mise en abyme; y (c) el realizador como personaje. Se concluye que la película es una producción propia de la estética contemporánea, marcada por narrativas cuya oferta de sentido problematiza el acceso a lo real, en el supuesto rompimiento con reglas canónicas del cine al romper la cuarta pared, haciendo de la pretendida disimulación de marcas de enunciación una importante articulación narrativa, con el fin de transgredir y dar visibilidad a la censura impuesta al país, al incorporar los bastidores a la trama principal, en el movimiento de la película de vuelta sobre sí misma.

Palabras-clave: Metanarrativa. Posmodernidad. Censura. Cine iraní. Jafar Panahi.

\section{A narrativa que olha para si}

Uma das implicações mais evidentes do contemporâneo no âmbito das expressões artísticas diz respeito ao forte sentido empregado na autorreflexão. Em um sentido inverso à neutralidade pregada pela Modernidade, as obras caracterizam-se por assumirem-se enquanto enunciados e sublinharem a inevitável subjetividade agora explícita. Ou seja, enquanto a arte moderna continha em si uma crítica à mercadoria, bem como um esforço no sentido de transcendê-la, no pós-moderno a própria cultura tende a se tornar um produto que especialmente fala sobre si, desde uma perspectiva metanarrativa.

A partir da aproximação entre os mundos da cultura popular e da arte erudita, como ensina Jameson (1997), novos tipos de textos impregnados de formas, categorias e conteúdos da chamada indústria cultural, outrora combatida pelos ideólogos da Modernidade, vão emergindo com a integração da produção estética à produção de mercadorias em geral. Assim, integrada a um sistema comercial, a produção estética é provocada a “entregar” novidades com uma velocidade cada vez maior, o que acaba por estimular a inovação estética e o experimentalismo (JAMESON, 1997). E, como consequência, o que se observa no decorrer das últimas décadas é o surgimento de manifestações artísticas que experimentam, questionam e ampliam os limites presumidos dos gêneros e da arte em si (HUTCHEON, 1991).

Segundo Hutcheon (1991), a arte pós-modernista ataca deliberadamente princípios como valor, ordem, sentido, controle e identidade, próprios da Modernidade. Os 
questionamentos universais dão lugar a uma ênfase maior ao local e ao particular - a cultura se transforma em “culturas” - e as concordâncias públicas são questionadas pela aceitação das diferenças na prática artística. Trata-se, segundo a autora, de um questionamento a qualquer sistema totalizante ou homogeneizante. Em razão disso, a arte pós-modernista, prossegue Hutcheon (1991), é intensamente autorreflexiva e consciente, portanto de que, nessa sociedade emergente, o acesso à realidade se dá de forma mediada, estruturada por múltiplos discursos, demandando o exame sobre si própria e sobre suas condições de produção. Nesse sentido, caem as pretensões de representações neutras de mundo, associadas à estética Moderna, dando lugar a expressões que, embora não deixem de representar, mostram-se conscientes e assumem explicitamente que o que representam é filtrado pela subjetividade do autor. A crise da representação, portanto, conclui a autora, leva à conclusão de que o esforço até então habitual de separação entre a arte e a vida tende a não ser mais válido.

Dessa forma, ainda que o pós-modernismo não seja, na visão de Hutcheon (1991), necessariamente uma negação do modernismo, e nem os textos contemporâneos substituam a verdade, a problematização da natureza do referente e a sua relação com o mundo real e histórico é própria das narrativas contemporâneas, evidenciadas na autorreflexividade metaficcional. Ou como diz Jameson (1997), a partir dessa nova consciência, os romances históricos, por exemplo, não podem mais se propor a representar o passado histórico, senão que representar as nossas ideias e estereótipos sobre o passado.

Na medida em que a arte é consciente da impossibilidade de acessar a realidade diretamente, a menos que pela mediação discursiva, a ficção deixa de ser compreendida como oposição à realidade e passa a ser aceita como uma alternativa de conhecimento sobre o mundo. O próprio conceito de “verdade”, portanto, defendido e pregado na Modernidade, passa a ser abandonado. As diferenças entre ficção e História, que são estudadas desde a tradição clássica, adquirem uma nova compreensão na teoria e na arte pós-modernas. As duas passam a ser identificadas como construções linguísticas e capazes de oferecer, não uma verdade objetiva, mas uma verossimilhança (ou aproximação) (HUTCHEON, 1991).

Nesse contexto, ganham relevância manifestações que desafiam as noções tradicionais de perspectiva e levantam suspeita sobre o próprio conceito de arte, dando um caráter múltiplo e difícil de localizar aos narradores e suas ficções. Dentre os expoentes deste fenômeno, estão as metaficções historiográficas - obras que têm por característica apropriarse de personagens e/ou acontecimentos históricos sob a ordem da problematização dos fatos concebidos como "verdadeiros" -, que foram longamente analisadas por Hutcheon (1991).

A autora chama de "paraliterárias" as obras que desafiam o conceito de "obra de arte”, tratando pelo que se costuma chamar de “dessacralização”. Segundo Jameson (1997), a linguagem antiga da "obra” tem sido deslocada pela linguagem do "texto" e da "textualidade” já que, uma vez que se assume a subjetividade como instância mediadora do acesso à realidade, tudo pode ser um texto - a vida cotidiana, o corpo, as representações políticas. Diz o autor (JAMESON, 1997, p. 101): “A obra de arte autônoma desse modo - juntamente com o velho sujeito autônomo ou ego -, parece ter desaparecido, ter-se 
volatilizado”. Neste sentido, a arte pós-moderna é contraditória, na medida em que, como não há mais a perspectiva de um horizonte de satisfação, não oferece uma alternativa àquilo que contesta. É também assim observado a partir do campo da cultura, que não se pode afirmar que a Pós-modernidade é necessariamente um novo paradigma, porque não substitui, ainda que questione, o humanismo liberal. As obras pós-modernas, diz, chamam a atenção para o que está sendo contestado, mas assumem o seu caráter provisório. E o pós-modernismo, portanto, “[...] não sugere nenhuma busca para encontrar um sentido atemporal transcendente, mas sim uma reavaliação e um diálogo em relação ao passado à luz do presente” (HUTCHEON, 1991, p. 39).

\section{Metanarrativa como autorreflexão}

Decorre deste processo de autoconsciência, em razão disso, movimentos da arte pós-moderna que, em alguns casos, de voltarem sobre si mesmas, justificando os processos metanarrativos no conjunto das experimentações e inovações estéticas surgidas a partir da transição da Modernidade para a Pós-modernidade. Ou como observam Andrade (1999) e Logde (2011), a capacidade de autorreflexão é uma das características mais marcantes da arte do século 20, entendida como “metaficção”, presente em obras que versam sobre si, que chamam a atenção para o seu status ficcional e para o próprio método de construção.

Já Bernardo (2010, p. 9) define o fenômeno estético autorreferente como aquele “[...] através do qual a ficção duplica-se por dentro, falando de si mesma ou contendo a si mesma”. Ou ainda Chalhub (1986) lembra que o prefixo "metá” remete-nos à sua etimologia grega, que significa “mudança”, “posterioridade”, “além”, “transcendência”, “reflexão”, “crítica sobre”. Por isso, diz a autora, a "metalinguagem” nada mais é do que a "linguagem da linguagem”. E a metanarrativa, por extensão, compreendida como a narrativa da narrativa.

Para Hutcheon (1980), trata-se de "narcisismo textual” as obras de caráter metanarrativo que propõem tornar o processo visível e explícito ao receptor. As narrativas, portanto, perseguem a ideia de se oferecerem neste processo, a partir das limitações da linguagem agora explicitadas, suas verdades e autenticidades, buscando reduzir o tanto quanto possível as mediações. E propondo, em nome desse mostrar-se, conquistar os públicos pela cumplicidade. Dentre os termos que, segundo Vaugh (1984), já foram utilizados para definir as obras de caráter metaficcional estão "romance introvertido”, “irrealismo”, "subficção”, "romance autogerador" e "fabulação”, indicando em suas denominações justamente a tomada de consciência da própria condição da obra, não de realidade, mas limitada a um discurso sobre a realidade. São obras, pois, que convocam o receptor a perceber que aquilo que está diante dele não se trata de uma reprodução direta do mundo e, sim, de uma mensagem organizada como um sistema de signos (linguagem) que evidencia e problematiza esse dizer. Portanto, não se trata “do mundo” e, sim, de uma leitura possível sobre o mundo, mediante a explicitação de que a subjetividade é indissociável de qualquer dizer e precisa ser tema de preocupação também, agora, a quem frui a obra. 
Na mesma linha, Hutcheon (1980) afirma que, na metanarrativa, a conexão entre a arte e a vida não é negada. É, sim, reforçada em um novo nível, o nível do processo imaginativo - a elaboração da história - ao invés do produto - a história contada. A metaficção, segundo a autora, é consequência, portanto, de um fenômeno cultural que diz respeito ao crescente interesse em como a arte é criada, e não apenas no que é criado. Ou seja, deixa-se de se interessar pela arte apenas e enquanto produto, para lançar o olhar também como processo, que pode ser tão instigante quanto.

A metanarrativa, pois, quebra o antigo “contrato de ilusão” entre o autor e o espectador, que orientava a arte até a modernidade. Segundo Bernardo (2010), essa relação ganha uma dimensão mais complexa, que passa por três processos. O primeiro é a tradicional "suspensão da descrença”. Ao ler um livro, assistir um filme ou apreciar uma pintura, é preciso fazê-lo "como se" o que lemos ou vemos é real - exatamente o que preconizava o realismo tradicional. Em um segundo momento, porém, ocorre a "suspensão da suspensão da descrença”, quando passamos a fazer da leitura e da observação da arte nosso ofício, ou seja, para entender o processo que provoca a suspensão da descrença. O terceiro momento é a "suspensão da crença", que subverte toda a lógica tradicional. É o momento em que se abandona a confiança nos sistemas e teorias - nas “estruturas sólidas” - e, sobretudo, no poder da arte de representar a realidade, ou seja, nos postulados da Modernidade.

Embora o fenômeno da metanarrativa se evidencie no contemporâneo, buscando especialmente capturar o receptor neste processo, como lembram Hutcheon (1980), Vaugh (1984) e Bernardo (2010), não se trata de algo novo. Os recursos metanarrativos já são experimentados pela literatura há mais tempo, numa prática tão antiga (ou mais) do que a do próprio romance, constituindo-se numa tendência ou função inerente a todos os romances.

Bernardo (2010, p. 16) caminha na mesma direção ao dizer que "Reconhecer ficção na verdade não a torna menos verdade, ao contrário - torna-a a nossa verdade, aquela que foi feita por nós. Reconhecer ficção na verdade, portanto, é um movimento responsável e responsabilizador”. Para a metanarrativa pós-moderna, portanto, a realidade, sim, existe além do texto, mas só pode ser atingida por meio dele, mais uma vez reafirmando a ideia de “transparência” dando lugar à “opacidade”. A única diferença entre a ficção e a realidade, portanto, é que a primeira é construída inteiramente com linguagem, o que permite algumas liberdades. A ficção, pois, simplesmente admite a existência de múltiplas realidades (VAUGH, 1984).

Para Vaugh (1984), na tentativa de definir o status ontológico da ficção, os teóricos tradicionalmente se dividiram em duas correntes. A primeira partia da premissa de que as ficções são claramente mentiras, na medida em que não haveria uma correspondência direta com a realidade material. A segunda envolve os teóricos não referenciais, que não consideravam apropriado discutir um status de "verdade” na ficção. O que surge no rastro da Pós-modernidade é uma terceira corrente, que não nega que a ficção encontra seus referentes na realidade e assume que a ficção oferece, não representações da realidade, mas "mundos possíveis" - é onde se situa a metanarrativa. 


\section{Panahi e o cinema metanarrativo e militante}

A produção fílmica de Jafar Panahi tem sido marcada pela recorrência à adoção dos recursos metanarrativos, desempenhando um duplo papel concernente tanto à estética e linguagem, por propor sentidos de autenticidade e reflexão sobre o próprio fazer neste caso cinematográfico, quanto com relação a constituir-se numa estratégia de denúncia e militância política, na medida em que problematiza o processo de produção do cinema. Isso legitimou a escolha de uma de suas produções, "Isto não é um filme", como exemplo desse movimento identificado no contemporâneo a respeito das estratégias metanarrativas no cinema, de modo que foi tomado como material de reflexão e análise.

Panahi é um diretor de cinema que não pode fazer filmes, graças às punições imputadas pela justiça iraniana em razão de ter retratado temas polêmicos da cultura do país em seus filmes, além de ser conhecido opositor ao regime político atual. A partir do período pós-Revolução Islâmica, desenvolveu-se no Irã um cinema político, em paralelo às correntes comerciais, dotado de uma linguagem simbólica que objetivava, sobretudo, driblar o aparato estatal repressivo, que se mantém até hoje. Assim, enquanto o cinema "oficial” reproduz as mensagens islâmicas, um cinema militante tem dado voz ao clamor por reformas e mudanças (MELEIRO, 2006).

Assim, especialmente com o aumento de cofinanciamentos com produtores estrangeiros, esses cineastas vêm buscando retratar, em seus filmes, as complexidades da sociedade iraniana, que permanecem ocultas na propaganda política do governo. São narrativas que objetivam denunciar e combater os estereótipos associados ao país que são difundidos mundo afora pelos sistemas internacionais de informação.

Jafar Panahi é um dos autores mais proeminentes dessa corrente. Após começar a carreira como assistente de Abbas Kiarostamil, estreou como diretor de longas-metragens com “O Balão Branco” (1995). Já em 1997, dirigiu “O Espelho”, obra na qual iniciou de forma mais significativa suas experimentações sobre os limites pouco claros entre a ficção e não ficção, bem como com a adoção de estratégias metanarrativas que cumprem essa função de embaralhar os bastidores com a trama do próprio filme.

A bem-sucedida trajetória de Panahi, que seguiu com filmes aclamados como " $O$ Círculo” (2000), “Ouro Carmim” (2003) e “Fora de Jogo” (2006), se estendeu até em 2010, quando sofreu uma inflexão com a prisão, pouco tempo após uma eleição presidencial em que havia apoiado, abertamente, o candidato de oposição. Panahi foi acusado de conspiração contra o regime e sua prisão repercutiu em todo o mundo e mobilizou a comunidade cinematográfica internacional.

Panahi acabou libertado apenas no fim de maio, mas sofreu uma dura condenação de seis anos de prisão domiciliar e vinte anos proibido de fazer filmes, sair do país ou conceder entrevistas (AMARAL, 2015). Apesar disso, seguiu produzindo filmes de forma clandestina, com o apoio discreto de colegas. Em 2010, lançou “Isto não é um filme”, em que documenta o seu encarceramento e discute a sua proibição de fazer filmes. A obra chegou ao Festival de 
Cannes, onde teve sua estreia mundial, levada pelo codiretor, Mojtaba Mirtahmasb, em um pendrive escondido dentro de um bolo.

Outros três filmes, também rodados clandestinamente, já foram lançados no período em que Panahi cumpre sua pena. “Cortinas Fechadas” (2013) foi filmado em uma casa de praia do diretor, no mar Cáspio. Na obra, Panahi novamente aparece em cena, mas dessa vez interagindo com personagens fictícios que representam as perseguições impostas pelo regime - como um escritor que se esconde com seu cachorro após os animais serem banidos, acusados de serem impuros sob a lei islâmica.

A restrição ao último grau no qual Panahi se encontra no atual estágio de sua carreira faz com que as experimentações de linguagem, em especial no que toca à mistura de ficção e não ficção, sejam aprofundadas nesses trabalhos mais recentes. No filme “Táxi Teerã” (2015), que recebeu o Urso de Ouro no Festival de Berlim, Panahi se passa por taxista e percorre as ruas de Teerã, carregando passageiros e é uma obra repleta de passagens metanarrativas. As situações, aparentemente “espontâneas”, registradas por uma câmera instalada no painel do veículo, acabam por oferecer um retrato da situação política do país. Na produção mais recente, “3 Faces” (2018), que estreou no Festival de Cannes do ano passado, Panahi novamente aparece na tela e traz também mais uma vez a temática da mulher. Na trama, ele e uma atriz de cinema, que também interpreta a si mesma, viajam a um vilarejo na fronteira com a Turquia em busca de uma jovem que havia escrito a Panahi, afirmando que cometeria suicídio por conta da pressão contrária da família às suas ambições artísticas.

\section{A resposta metanarrativa à censura}

Para proceder a análise da produção “Isto não é um filme”, foram adotadas categorias resultantes de padrões de repetição observados ao longo da análise exploratória inicial e que se articulam às proposições teóricas trabalhadas neste artigo. Assim, "Isto não é um filme” é analisado a partir das categorias: a) a câmera como elemento intradigético e metanarrativo; b) o mise en abyme, e c) o realizador como personagem.

\section{A câmera como elemento intradigético e metanarrativo}

“Isto não é um filme” foi escolhido para análise neste artigo porque se trata de uma das produções em que o roteiro foi resultado, justamente, dos constrangimentos e sanções penais a que Panahi está submetido. Sem poder filmar, o cineasta fez da interdição a linguagem do filme, legitimando esteticamente, assim, a adoção de estratégias metanarrativas em roteiros possíveis de serem executados e, mediante a oportuna "mistura" entre o filme e seus bastidores. Assim, "Isto não é um filme” se apresenta como um registro bruto de um dia da sua prisão domiciliar - sugestivamente, em meio ao tradicional festival de fogos no Irã, quando são lançados fogos de artifício e feitas grandes fogueiras nas ruas para celebrar a chegada do ano novo, segundo o calendário persa. 
O filme se passa, quase integralmente, dentro do apartamento de Panahi. Logo no início, ele telefona para um amigo e pede que vá até lá. Seu objetivo, ante a condenação judicial, é apresentar o filme que gostaria de fazer, mas não pode. Passa, então, diante da câmera conduzida pelo amigo, a ler um roteiro barrado pela censura, descrevendo o que imaginava em termos de cenários, composição dos planos, diálogos, movimentos dos atores etc. Em meio a isso, Panahi aparece falando com sua advogada ao telefone sobre o andamento de seu processo (ele ainda aguardava o julgamento de um recurso junto ao Tribunal de Apelação), fazendo relatos sobre seus filmes anteriores, alimentando um lagarto de estimação e em contatos com vizinhos do prédio, entre outros. Parte das imagens foram captadas pela câmera de um aparelho celular.

A câmera que registra as imagens exibidas na tela é um elemento intradiegético, ou seja, está dentro do texto, compõe a situação retratada e os personagens se mostram, em geral, conscientes de sua presença e com frequência interagem com ela. É o que Aumont (1995) chamou de fenômeno de diegetização, quando um elemento externo à narração é incorporado a ela. No entanto, em “Isto não é um filme”, essa característica não é evidente nos minutos iniciais. Na primeira cena, Panahi aparece tomando café da manhã e falando ao telefone, mas não se volta à câmera. Esse reconhecimento só se dá na segunda sequência, quando a imagem mostra um quarto vazio e uma cama desfeita e ouve-se um recado deixados na secretária eletrônica pela esposa e filho de Panahi. Em dado momento, o filho diz:

- Papai, ouça, eu liguei a câmera e a coloquei na cadeira. Só acho que não há muita carga. A bateria pode acabar.

Panahi, então, surge no plano, se volta para a câmera, vai até ela e sai do quarto com o equipamento na mão. Compreende-se, pois, que a câmera deixada na cadeira, conforme relatado pelo filho, era exatamente a câmera que registrava aquela imagem, bem como de todas as passagens seguintes. As interações com a câmera seguem durante todo o filme. Já na sequência, com a continuidade do filme, fica claro que quem está conduzindo a câmera é o amigo que Panahi chamou por telefone - que, inicialmente, não é nominado e não aparece na tela -, com quem o cineasta mantém diálogo. Em vários momentos - como quando Panahi está lendo o roteiro que gostaria de filmar e quando fala sobre seus filmes anteriores -, se volta diretamente à lente, o que faz com que seu olho encontre o olho do espectador, quebrando a tradicional quarta parede e instaurando relações de cumplicidade entre ele e sua suposta audiência (Figura 1). 
Figura 1 - Sequência de "Isto não é um filme"

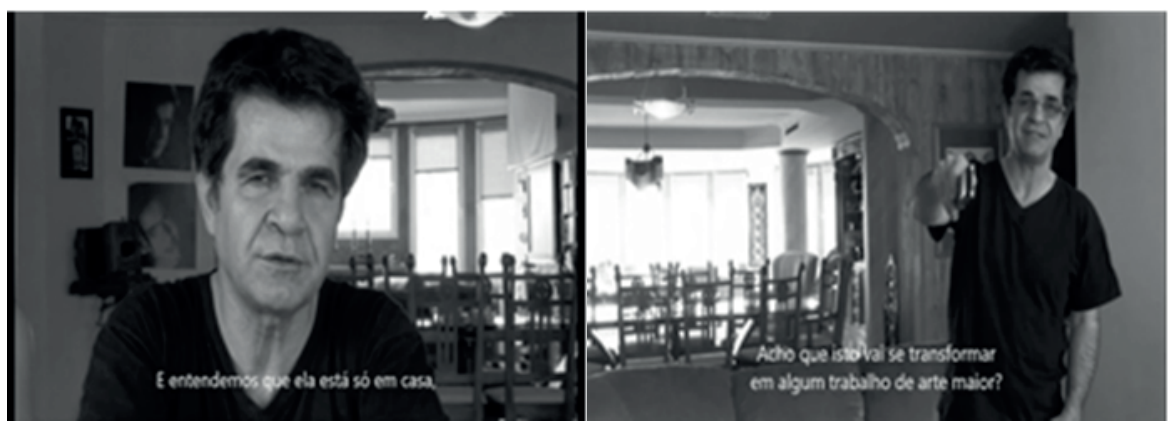

Fonte: “Isto não é um filme”, Jafar Panahi, 2010.

O filme tem passagens em que o ponto de vista do espectador se desloca, na medida em que outras câmeras entram em cena, em uma espécie de ampliação do fenômeno de diegetização. Em “Isto não é um filme”, isso ocorre quando Panahi resolve sacar um telefone móvel e as imagens da câmera principal passam a se intercalar, por meio da montagem, com as imagens captadas pela câmera do celular. A própria câmera principal aparece, bem como o amigo de Panahi que a conduz (Figura 2).

Figura 2 - Sequência de "Isto não é um filme”

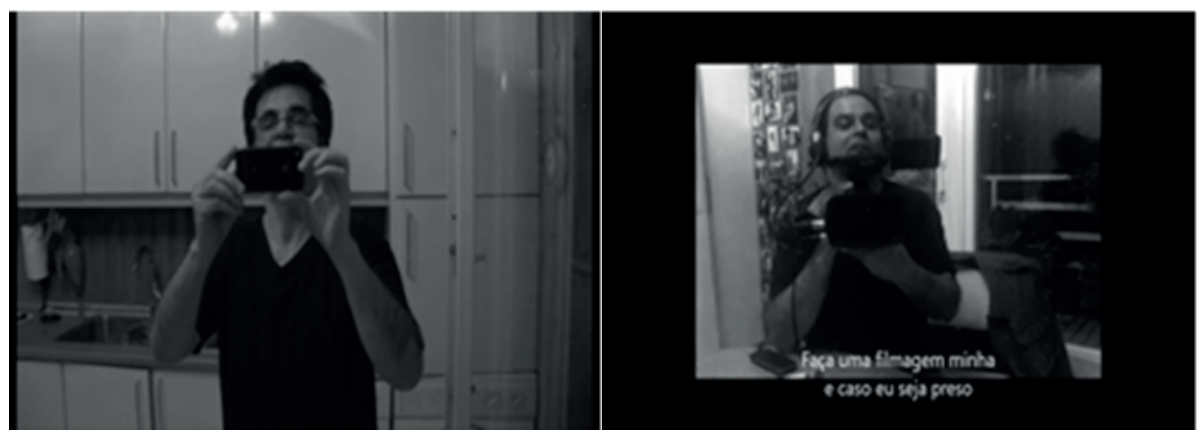

Fonte: “Isto não é um filme”, Jafar Panahi, 2010.

Esses personagens assumem a posição do que Gaudreault e Jost (2009) chamam de narradores delegados ou narradores segundos. A condução da narrativa segue a cargo do diretor, o que significa que a atividade à qual esses personagens se entregam é a subnarração. São diferentes níveis narrativos que se sobrepõem nas obras: o ponto de vista de personagens, porém, subjugados ao ponto de vista dado a ver pelo diretor.

Vê-se, pois, que Panahi se vale de diversos recursos que sublinham a enunciação fílmica em suas obras. Quando indica-se que o amigo de Panahi está conduzindo a câmera e quando o próprio Panahi assume a condução da narrativa com o celular e depois com a câmera principal em “Isto não é um filme”, o que se verifica é um movimento em que o ponto 
de vista destes personagens se torna o ponto de vista do espectador. Não há aqui, portanto, qualquer pretensão de neutralidade, já que se sabe que há alguém por trás da imagem que se vê na tela.

O que subjazà inserção da câmera como um elemento intradiegético éo reconhecimento da linguagem e da adoção do recurso metanarrativo por excelência. Enquanto o cinema “clássico”, conforme lembravam Metz (1980), Aumont (1995), Furtado (2005) e Gaudreault e Jost (2009), buscava o apagamento das marcas de enunciação nos filmes, com os personagens ignorando a câmera, aqui o que se persegue é exatamente o oposto. Na medida em que a câmera compõe a situação que é retratada e os personagens fazem referência a ela a todo momento - inclusive se voltando diretamente a ela em várias situações -, os filmes estão expondo seus códigos e se reconhecendo como filmes. Ou seja, como discursos, ainda que se proponham a oferecer leituras sobre a realidade.

Com a presença da câmera, portanto, deixa-se de encobrir o processo de elaboração das obras. Conforme explica Bernardo (2010), nos processos metanarrativos, o foco não se volta apenas à situação retratada, mas também ao método de construção, o que fica evidente, por exemplo, nas passagens em que os personagens manipulam deliberadamente a direção da câmera. O filme sendo realizado fica ainda mais exposto quando os personagens se valem de outras câmeras para fazer gravações sob outros pontos de vista, passando também a compor, simultaneamente, os filmes. A subjetividade, pois, está explícita e “pede” para ser identificada.

Na verdade, o simples fato de o filme mesclar imagens que, notoriamente, foram captadas por múltiplas câmeras já sinaliza para a subjetividade e sua implicação no trabalho de montagem. Assim, por mais que haja uma aparência de "pureza” na estética dos filmes, a incidência da montagem pressupõe algum nível de ressignificação na medida em que, após captadas, as imagens foram reorganizadas pelo realizador. É por isso que Gaudreault e Jost (2009) afirmam que a edição é um dos meios pelos quais se dá o reconhecimento da enunciação fílmica. No presente caso, a coexistência de câmeras intradiegéticas é uma das chaves.

Mais do que subverter uma tradição do cinema, essa estratégia rompe com a pretensão do projeto realista de oferecer representações diretas da realidade social, conforme analisaram Jaguaribe (2007) e Margato (2012), e se alia a uma inclinação da arte pós-modernista de problematizar a relação entre a obra e o mundo real e histórico. Como dito, parece claro que Panahi quer, sim, entregar informações sobre a realidade, mas ao adotar essa estratégia, assume que o que está na tela não é a realidade em si, mas uma observação possível sobre ela.

No que toca às passagens em que outras câmeras entram em cena, a estratégia parece ser dotada também de algum cunho ideológico e de denúncia. Quando Panahi saca o celular em “Isto não é um filme”, os dois travam o seguinte diálogo: 
Amigo - Ótimo. Você gravou também.

Panahi - Que proveito há nisto? A qualidade é muito baixa.

Amigo - Escute, Jafar, creio que o que importa é o que está sendo documentado.

Fica evidente que, não é sem significação que Panahi incluiu as “subnarrações” nos filmes. Ao reconhecer o valor de uma câmera de celular, apesar da baixa qualidade, o autor não apenas desafia o cerceamento imposto pela sua condenação e as normatizações a que está subordinada a produção cinematográfica no Irã, já que os diretores dependem de autorizações prévias do Estado para se valer de equipamentos para fazer filmes, como assume seu caráter de militância, ao desafiar o próprio conceito de obra de arte. O movimento pós-modernista se põe contra o formalismo e valores tradicionais de cronologia e sentido, a partir da assunção da subjetividade e da ideia de que o cotidiano e o prosaico também podem ser texto.

\section{O mise en abyme}

Nesse mesmo movimento autorreferencial, o filme carrega inúmeras referências a trabalhos anteriores de Panahi, inclusive com menções diretas feitas por personagens e até na reprodução de trechos desses trabalhos, levando a uma ideia última de que todos os filmes possam também ser vistos e compreendidos como um só. É o que se pode chamar de mise en abyme (MOUSINHO; OLIVEIRA, 2017). A técnica, que também é empregada em outras expressões artísticas, como na pintura, consiste em "pôr em abismo", a obra dentro da obra, o filme dentro do filme. É o que ocorre quando há diferentes camadas narrativas superpostas na imagem e um personagem assiste ou faz referência a outro filme, movimento tipicamente metanarrativo.

Em “Isto não é um filme”, essas ocorrências são bastante explícitas. Ainda nas sequências iniciais, Panahi aparece falando sobre "O Espelho", com uma passagem do filme sendo reproduzida em uma televisão diante da qual ele está e se dirige diretamente à câmera, comentando sobre a situação vivida pela protagonista. Há, ainda, outras duas passagens semelhantes. Diante da mesma televisão, Panahi assiste a trechos de "Ouro Carmim” e "O Círculo”. Nestes casos, ele avança fazendo comentários sobre o processo produtivo dos filmes, expondo mais uma vez, portanto, os códigos de linguagem do cinema. Sobre “Ouro Carmim”, comenta o uso de não atores e a interpretação espontânea do protagonista em uma cena específica, elementos que reforçam a ideia de autenticidade e organicidade da obra. "Com um ator amador como Hossein, os detalhes não serão previsíveis. Você escreve algumas coisas, mas quando está na locação e o ator entra, ele dirige você" (PANAHI, 2010).

Já sobre “O Círculo”, o diretor fala da importância da locação a partir de um trecho específico, em que uma personagem desesperada corre dentro de um prédio, cuja estrutura 
é formada por linhas verticais. "Aqui, a locação está dirigindo. A atriz não precisou fazer esforço para mostrar sua ansiedade. Aquelas linhas verticais da locação... Aquelas linhas supriram seu estado mental” (Figura 3).

Figura 3 - Sequência de "Isto não é um filme"

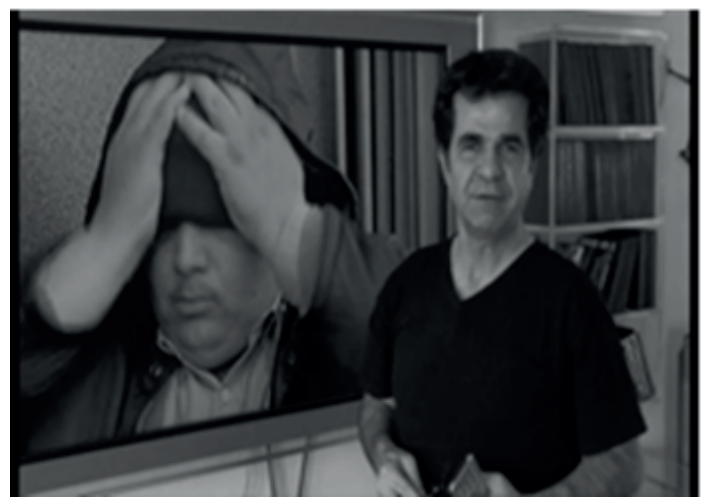

Fonte: “Isto não é um filme”, Jafar Panahi, 2010.

Além disso, Panahi textualmente endossa alguns dos preceitos teóricos que embasam o mise en abyme. Ao afirmar, por exemplo, que "o ator dirige você", nada mais faz do que confirmar a existência de subnarrações em suas obras, em acordo com que dizem Gautreauld e Jost (2009), quando afirmam que os personagens também conduzem as narrativas, embora subordinados ao realizador. O mesmo que ocorre quando Panahi afirma que "o cenário dirige”, na tentativa de, mais uma vez, sublinhar a subjetividade, ao indicar que há narradores por trás dos enunciados fílmicos e chamar a atenção para as complexificações geradas a partir da existência de diferentes níveis narrativos em seus próprios filmes. As referências são inúmeras em "Isto não é um filme”.

\section{$O$ realizador como personagem}

As estratégias adotadas por Panahi ao fazer um filme sobre o filme que não pôde fazer, no processo metanarrativo de mise en abyme, conta ainda com a adoção da ideia do próprio realizador como personagem de si mesmo. Em “Isto não é um filme”, Panahi não só toma a frente da cena, como traz o seu drama pessoal ao centro, o que dá um caráter autobiográfico ao filme. Isso fica evidente a partir de uma das sequências iniciais, em que ele conversa por telefone com a advogada sobre o andamento de seu recurso de apelação contra a sentença condenatória. A advogada relata a ele que dificilmente será possível reverter a punição e que só pressões internas e externas são capazes de amenizar a sua pena. Sugere, também, que o processo sofre interferências políticas: "Eu deveria dizer pura e simplesmente que as decisões são 100\% políticas e nada legais ou jurídicas. Tudo depende das condições sociais correntes e das pressões e reações”, afirma. 
Mais adiante, quando explica sua intenção de apresentar o roteiro do filme que não foi autorizado a rodar, ele faz menção direta à sua conhecida sentença: "Até agora diz: vinte anos proibido de fazer cinema, vinte anos proibido de escrever roteiros, vinte anos proibido de sair do país, vinte anos proibido de conceder entrevistas. Atuação e leitura de roteiro não foram mencionados”. Nessa mesma passagem, Panahi faz um relato sobre a rejeição de seu roteiro pelos órgãos de censura: "Disseram-me que fizesse alterações no roteiro e que eu adoçasse um pouco para ver se conseguiria permissão, mas ainda assim eu não consegui anuência e não me permitiram trabalhar”. Em outro momento, conta sobre um filme que foi interditado durante as gravações. Apenas uma obra que assume a subjetividade é capaz de colocar o criador em evidência - já que, em um movimento inverso, a intenção seria "mascarar” a sua interferência em nome de uma suposta reprodução fiel da realidade social. Nesse caso, dá-se o reconhecimento de que o autor é uma instância também construída no próprio texto (BERNARDO, 2010).

Mais do que isso, ao abordar diretamente o processo do qual é alvo, noticiado em todo o mundo, Panahi deixa claro o propósito político de suas obras. Ao desafiar a proibição de fazer filmes, valendo-se da tecnologia disponível na atualidade que compromete o controle estatal sobre a produção audiovisual, e trazer à tona a sua história em obras que obtiveram colocações nos mais importantes festivais de cinema internacionais e, inclusive, em circuitos comerciais ocidentais, Panahi busca mais uma vez exercer sua vocação militante, denunciando ao planeta uma coerção abusiva e constrangendo um regime que insiste no autoritarismo e no silenciamento das vozes dissonantes.

O recurso autorreferencial, nesse caso, é o instrumento por meio do qual o diretor desvia do cerceamento e, ao falar de si, chama a atenção para todas as injustiças geradas por um sistema político restritivo e para o fato de ainda existirem privações de liberdades no contemporâneo, reivindicando o poder das artes e do cinema de resistir a isso. Essa postura é alicerçada no movimento pós-modernista, em que as instituições passam a ser questionadas, as antigas referências se perdem e, com um componente comunicacional cada vez mais evidente, o poder de regulagem se desloca dos administradores para os autômatos e as autoridades, embora ainda existam, não conseguem mais impor sua fala (ANDERSON, 1999, LYOTARD, 2004).

Com “Isto não é um filme”, Panahi, sem se aliar a nenhuma força tradicional (esquerda ou direita, por exemplo), põe em xeque o poder tanto dos órgãos reguladores da produção cinematográfica iraniana como de todo o aparato estatal, na medida em que descumpre uma decisão judicial. Ainda que a mistura de elementos ficcionais e não ficcionais seja uma marca do cinema iraniano contemporâneo e, inclusive, já explorada em obras anteriores de Jafar Panahi, nos filmes produzidos durante sua prisão domiciliar esse tensionamento é elevado a um novo patamar de complexificação. Durante suas passagens pelos circuitos comerciais e de festivais, os filmes desorientaram a audiência quanto à sua natureza, o que fica claro em reportagens e críticas jornalísticas que ora referem-se às obras como documentais, sinalizando para uma crença de que se tratam de registros brutos de situações não encenadas por câmeras 
imparciais. Ora referem-se como “falsos documentários”, indicando um reconhecimento de que são obras de caráter ficcional, mas que se valem de códigos naturalistas como estratégia.

Além de não dar sinais claros de suas pretensões no que toca à correspondência com a realidade social, Panahi quer provocar a reflexão sobre os limites entre ficção e não ficção para o interior dos filmes. Em "Isto não é um filme”, no primeiro diálogo entre ele e o amigo, o diretor relata ter feito sozinho gravações com a câmera, que correspondem às imagens de abertura do filme, mas que diz não ter ficado satisfeito, porque pareciam falsas:

- Esta manhã, depois que conversamos ao telefone, eu me sentei e revi as gravações do que já havia filmado. Eu me dei conta que, de alguma forma, parecia fingimento. Está se transformando em uma mentira. E que, de alguma forma, não sou eu.

Mais adiante, mesmo com a câmera sob a tutela do colega, Panahi se vê diante do mesmo problema:

- Talvez eu esteja marcando o tempo. Sinto que o que estamos fazendo aqui é uma mentira, como a primeira sequência que vimos. O resto, certamente, virá a ser mentiras, não importa como proceda.

O que Panahi parece reconhecer, uma vez mais, é a inevitabilidade da ficcionalização. Por mais que sua intenção seja oferecer o acesso à realidade, reduzindo os filtros e intermediações, a própria narrativa expõe a impossibilidade da objetividade absoluta, resultando daí o conflito em relação ao que está filmando que, ironicamente, não se sabe mais se é espontâneo ou concebido.

Em "Isto não é um filme”, por exemplo, há longas passagens de Panahi alimentando o lagarto de estimação, assistindo televisão, abrindo a porta para uma vizinha que pede a ele que cuide de seu cachorro por algumas horas e um longo diálogo dentro de um elevador com um jovem que bate em seu apartamento para recolher o lixo. Todas essas situações, aparentemente espontâneas, embora não forneçam nenhuma informação importante sobre a trama, parecem buscar ofertar o sentido de uma autenticidade ao filme, uma vez que aconteceram "de verdade".

\section{Considerações finais}

A complexidade do cinema apresentado por Panahi diz respeito ao fato de que, valendo-se dos códigos e técnicas associadas aos documentários, portanto, pretensamente uma narrativa de "real", problematiza justamente, por meio dos recursos metanarrativos, seu caráter ficcional. Ao assumir a subjetividade e sua inexorabilidade, com o claro propósito de oferecer uma informação sobre a realidade, Panahi aposta na fiç̧ão como alternativa de 
conhecimento sobre o mundo, ao admitir que nada do que está na tela é, de fato, espontâneo. Portanto, é pela ficcionalização que se revelam as "verdades".

Em "Isto não é um filme”, a superposição de diferentes níveis narrativos faz com que a posição do narrador se desloque ao longo do filme. Assim, o ponto de vista do espectador passa a ser, temporariamente, o ponto de vista de personagens que conduzem câmeras intradiegéticas. Da mesma forma, quando o filme expõe seus códigos de criação, ao mostrar personagens manipulando câmeras, propondo reflexões sobre o fazer fílmico e fazendo referências diretas ao realizador, que também é personagem bem como sua história particular é tema, complexifica-se os níveis narrativos e a instância da enunciação (o filme sendo feito) e a instância do enunciado (o filme em si) que passam a coexistir na tela.

Assim, observa-se que o diretor elege uma determinada linguagem narrativa em função de sua capacidade de, ao oferecer uma visão sobre uma realidade afílmica que diz respeito ao contexto político do país, denunciar a censura imposta à produção cinematográfica e a arbitrariedade de sua condenação judicial e privação de produzir filmes. O reconhecimento do status ficcional e da impossibilidade de apreensão direta da realidade afílmica, põe em evidência, acabando por fragilizar a dicotomia realidade/ilusão.

Em “Isto não é um filme”, as estruturas ficcionais clássicas são rompidas, portanto, na medida em que os filmes respondem à demanda contemporânea por expressões e produtos que ofereçam “aparências de não intermediação subjetiva”. E na mesma proporção, Panahi parece brincar, por meio da ironia da linguagem, ao evocar a inevitabilidade da ficcionalização e da possibilidade de acesso direto à realidade afílmica. Os movimentos metanarrativos tornam explícita e ostensiva a presença do realizador (enunciador) no filme, que a todo momento orienta o espectador a perceber a sua interferência subjetiva, negando a neutralidade da imagem e da própria aparência de realidade oferecida pelas opções estéticas. Embora retrate um contexto político particular do Irã e faça referência à trajetória particular de Panahi, oferecendo comentários e reflexões acerca de todas essas circunstâncias, o filme é, acima de tudo, um filme sobre o cinema.

Ao radicalizar as potencialidades narrativas da chamada sétima arte, tensionando à última potência os limites entre a ficção e a não ficção, o que os filmes fazem é jogar luz sobre esses limites diante do espectador, ao invés de escamoteá-los. Com este título, Panahi também ironiza os limites impostos à sua atividade enquanto realizador, negando estar fazendo o filme e se valendo de brechas no texto legal para tentar provar que o que está expresso na imagem não é uma ficcionalização e, sim, um registro direto da realidade afílmica. Como ele próprio reconhece a inevitabilidade da ficção, “Isto não é um filme” não passa de uma ousada “dissimulação” perante aos seus censores. Faz-se um filme sem dizê-lo.

\section{Referências}

AMARAL, A. A representação da mulher em O Círculo de Jafar Panahi: o Irã, o Islã e o cinema (1979-2001). 2015. Dissertação (Mestrado em História) - Pontifícia Universidade Católica de São Paulo, São Paulo, 2015. 
ANDERSON, P. As origens da pós-modernidade. Rio de Janeiro: J. Zahar, 1999.

ANDRADE, A. L. O filme dentro do filme: a metalinguagem no cinema. Belo Horizonte: Editora UFMG, 1999. AUMONT, J. et al. A estética do filme. Campinas: Papirus, 1995.

BERNARDO, G. O livro da metaficção. Rio de Janeiro: Tinta Negra, 2010.

CHALHUB, S. A metalinguagem. São Paulo: Ática, 1986.

GAUDREAULT, A.; JOST, F. A narrativa cinematográfica. Brasília: Ed. da UnB, 2009.

HUTCHEON, L. Narcissistic narrative: the metafictional paradox. Waterloo: Wilfrid Laurier University Press, 1980.

HUTCHEON, L. Poética do pós-modernismo: história, teoria, ficção. Rio de Janeiro: Imago, 1991.

HUYSSEN, A. Mapeando o pós-moderno. In: HOLLANDA, H. B. de (Org.). Pós-modernismo e política. 2. ed. Rio de Janeiro: Rocco, 1992. 273p.

JAGUARIBE, B. O choque do real. Estética, mídia e cultura. Rio de Janeiro: Rocco, 2009.

JAMESON, F. Pós-modernismo: a lógica cultural do capitalismo tardio. São Paulo: Ática, 1997.

LODGE, D. A arte da ficção. Porto Alegre: L\&PM Pocket, 2011.

LYOTARD, J. F. A condição pós-moderna. Rio de Janeiro: J. Olympio, 2004.

MARGATO, I. Realismo, ou a arte de criar mundos. In: GOMES, R. C.; M, I. (Orgs.). Novos realismos. Belo Horizonte: Editora UFMG, 2012.

MELEIRO, A. O novo cinema iraniano: arte e intervenção social. São Paulo, Escrituras Editora, 2006.

METZ, C. Linguagem e cinema. São Paulo: Ed. Perspectiva, 1980.

MOUSINHO, L. A.; OLIVEIRA, R. M. M. O. Os dispositivos metaficcionais e a imbricação de forma e conteúdo em O Artista. Revista Livre de Cinema, João Pessoa, v. 5, n. 1, p. 4-15, jan./abr. 2018. Disponível em: http://www.relici.org.br/index.php/relici/article/view/166. Acesso em: 17 jan. 2018.

VAUGH, P. Metafiction: the theory and practice of self-conscious fiction. Londres: Routledge, 1984.

\section{Pedro Piccoli Garcia}

É graduado em Comunicação Social - Jornalismo pela Universidade de Santa Cruz do Sul (2011) e mestre em Letras pela mesma instituição (2018). Atua, desde 2010, no Jornal Gazeta do Sul, onde atualmente é editor de Política e Economia, revisor e colunista. Tem experiência na área de Comunicação, com ênfase em Narrativas Midiáticas. E-mail: pedropiccoligarcia@gmail.com.

\section{Fabiana Quatrin Piccinin}

É graduada em Comunicação Social - Jornalismo pela Universidade Federal de Santa Maria (1992), licenciada em Letras-Inglês pela Universidade de Santa Cruz do Sul (2015) e doutora pelo Programa de Pós-Graduação em Comunicação da Pontifícia Universidade Católica do Rio Grande do Sul (2007). É professora adjunta da Universidade de Santa Cruz do Sul, onde atua como professora do Departamento de Comunicação Social e professora e pesquisadora do Programa de Mestrado e Doutorado em Letras da Unisc. Atualmente é Coordenadora de Pós-Graduação Stricto Sensu da 
Universidade de Santa Cruz do Sul. Tem experiência na área de Comunicação, com ênfase em Teorias do Jornalismo, Jornalismo e Literatura, Narrativas Jornalísticas e Midiáticas, Jornalismo, Representações e Identidades, Telejornalismo e novas tecnologias. É vice-coordenadora do grupo de pesquisa “Grupo de Estudos de Narrativas Literárias e Midiáticas” (GENALIM-CNPq). Integra o Grupo de Ações e Intervenções Autopoéticas (Gaia-CNPq), o Grupo Pesquisa Mundial de Valores (World Values Survey) (UFRGS-CNPq) e o Grupo Interinstitucional de Pesquisa em Telejornalismo (GIP-Tele). Faz parte da RENAMI, Rede de Narrativas Midiáticas e da Rede de Telejornalismo, ambas ligadas à SBPjor (Sociedade Brasileira de Pesquisadores de Jornalismo) e da US International Exchange Alumni e é associada à AEJMC (Association for Education in Journalism and Mass Communication). E-mail: fabi@unisc.br.

Recebido em: 23.06.2019

Aprovado em: 16.09 .2020 